https://doi.org/10.52240/1857-2367.2020.2(21).32

\title{
FLORA HALOFILĂ DIN PAJIȘTEA „TODIREȘTI”
}

\author{
Ghenadie TITICA, Alina PAVLIUC \\ Grădina Botanică Națională (Institut) „Al. Ciubotaru”, \\ Chișinău, Repiblica Moldova
}

\begin{abstract}
The results of the research conducted in 2017-2018 are presented in this article. The present paper analyses the vascular flora of the "Todirești" halophile meadow from the Todiresti commune, Ungheni district. The "Todirești" halophile meadow has an area of about 44.52 ha and is found in the eastern part of commune. We have recorded 83 species of vascular plants belonging to 61 genera and 24 families. In the halophile meadow, 37 species of halophiles (44.6\% of the total number of species) have been identified. The flora has been analysed in terms of taxonomy, life forms, geoelements, ecological index and economical importance. Three rare species with different conservation status have been identified.
\end{abstract}

Key words: flora, halophytes, vascular plants, rare species.

Pajiștea halofilă „Todirești” ocupă suprafața de 44,52 ha. Flora pajiștei include 83 de specii de plante vasculare, care aparțin la 61 genuri, 24 familii, 21 ordine și 9 subclase, din clasele Magnoliopsida și Liliopsida, încrengătura Magnoliophyta.

Cel mai răspândit gen este Plantago (5 sp. - 6\%), urmat de Atriplex și Typha (cu câte 3 sp. $-3,6 \%)$.

Cele mai reprezentative familii sunt: Asteraceae (14 sp. - 16,8\%), Poaceae și Chenopodiaceae (11 sp. - 13,2\%), Brassicaceae, Fabaceae (6 sp. - 7,2\%), Plantaginaceae (5 sp. - 6\%), Polygonaceae, Cyperaceae, Typhaceae și Caryophyllaceae cu câte 3 specii fiecare, ceea ce constituie $3,6 \%$. 
Conform analizei bioformelor, speciile de plante se încadrează în cinci categorii. Hemicriptofitele prevalează în compoziția floristică $(39,7 \%)$, ceea ce indică prezența unui climat temperat favorabil pajiștilor. Terofitele constituie $35 \%$ și scot în evidență influența factorului antropic. Geofitele alcătuiesc $15,6 \%$, iar hidroheliofitele și camefitele totalizează împreună câte $4,8 \%$ fiecare. Conform analizei după durata de viaţă este evidentă prezența speciilor de plante perene, (53 sp.- sau 63,8\%), urmate de speciile de plante anuale (27 sp. $-32,5 \%)$ și speciile bianuale ( 3 sp. $-3,6 \%$ ).

Geoelementele în zona de studiu se încadrează în nouă categorii. Predominante sub aspect geografic sunt elementele euroasiatice cu $49,3 \%$, urmate de specille cosmopolite cu 14,4\% și continentale cu 13,2\%. Elementul pontic și circumpolar deține cîte 7,2\% fiecare, iar cel european doar 3,6\%. Elementele central-europene, adventive și mediteranene deţin câte $1,2 \%$.

Analiza florei în baza indicilor de umiditate (U) evidenţiază predominarea în zona de studiu a xero-mezofitelor $\left(\mathrm{U}_{2-2,5}-35 \%\right.$, mezofitelor $\left(\mathrm{U}_{3-3,5}\right)-23 \%$ și mezo-higrofitelor $\left(\mathrm{U}_{4-}\right.$ $\left.{ }_{4,5}\right) \mathrm{cu} 19 \%$. Conform cerințelor speciilor față de temperatură (T), flora pajiștii se încadrează în patru categorii ecologice. Cele mai multe sunt speciile micro-mezoterme $\left(\mathrm{T}_{3-3,5}\right)-45,7 \%$, urmate de cele amfitolerante $\left(\mathrm{T}_{0}\right)$ cu $31,3 \%$ și moderat-termofite $\left(\mathrm{T}_{4-4,5}\right)-23 \%$. Sub aspectul reacţiei solului $(\mathrm{R})$, flora pajiștei se încadrează în cinci categorii ecologice. Procentul cel mai mare îl dețin speciile amfitolerante $\left(\mathrm{R}_{0}\right)-41 \%$, urmate de cele slab acid-neutrofite $\left(T_{4-4,5}\right)-29 \%$. Specificul zonei de studiu scoate în evidență dezvoltarea pajiștilor de luncă halofilă, care sunt afectate de xerofitizare a florei.

În ceea ce priveşte cerinţele plantelor faţă de troficitatea solului, se remarcă dominarea speciilor eutrofe cu $37,3 \%$ şi mezotrofe cu $18 \%$.

În compoziția floristică au fost evidenţiate 10 specii de plante indicatoare pentru un anumit grad de aprovizionare al solului cu azot. Dintre acestea, mai numeroase sunt plantele de soluri mijlociu (N3-4,8\%) şi cele pe soluri slab aprovizionate (N2-2,4\%). Pe solurile sărăturate, din zona de studiu, au fost înregistrate 37 specii de plante halofile, care deţin $44,6 \%$ din flora pajiștii.

Valoarea economică a florei vasculare este reprezentată de plantele medicinale cu $56,6 \%$, urmate de cele furajere cu $24 \%$, alimentare și industriale câte $8,4 \%$ fiecare, decorative și toxice cu $1,2 \%$.

Î̉n conformitate cu clasificarea internaţională a speciilor periclitate IUCN (1994), în zona de studiu au fost identificate următoarele categorii de plante: rare $(\mathrm{R})$ - 2 specii (Iris halophila și Typha laxmannii), nedeterminate (I) - 1 specie (Camphorosma monspeliaca). Statut de protecție conform Legii privind fondul ariilor naturale protejate de stat (1998) are doar specia Typha laxmannii care este inclusă la categoria de specii rare, iar Iris halophila și Camphorosma monspeliaca sunt specii vulnerabile incluse în Lista roșie a plantelor superioare din România (1994).

\section{BIBLIOGRAFIE}

1. Ciocârlan V. Flora ilustrată a României: Pteridophyta et Spermatophyta. Bucureşti, Cereş, 2009, 1141 p.

2. Postolache Gh. Vegetaţia Republicii Moldova. Chişinău, 1995, 340 p.

3. Titica G., Pavliuc A. Vegetația halofilă din pajiștea „Todirești”. In: Revista Botanică. Vol. XI, nr. 2 (19), Chișinău, 2019, p. 28-37. 